UDC 26:316.77(045)

DOI: $10.21847 / 1728-9343.2019 .1(159) .157939$

FYLYPCHUK SVITLANA,

National University "Ostroh Academy" (Ostroh, Ukraine)

e-mail: svitlana.fylypchuk@oa.edu.ua, ORCID 0000-0001-5345-328X

\title{
SPECIAL SPHERES OF THE UGCC CHARITABLE ACTIVITY IN THE LIGHT OF CONFESSIONAL MEDIA: RELIGIOUS ANALYSIS
}

The specific directions and forms of social activity of the UGCC during the period of independence in the aspect of philanthropy are considered. Detailed analysis of the spiritual care of people with various physical and mental inferiority, serious illnesses and homeless in the light of church media is made. It has been found out that the deaconion, or the social ministry of the Church, is called to spiritual care for the following layers of the population by the means of social service of the marginalized society, such as abandoned with either physical and mental disability, or loneliness, or being in a particular life situation, etc. It is emphasized on the religious motivation of the volunteer activity of priests and believers in such pastoral care. It was emphasized that active development of civil society and personal religiosity contributed to the formation of an entire network of various forms of social and charitable activities.

Key words: charitable activity; media; extracurricular activities; UGCC.

Introduction. Permanently complicated country's social and politic situation necessitates Christian denominations' charitable activity aimed at special social groups. Deaconion, or social service of the Church, historically contingent non-cult activity of the Church, determined by deep religious inducements and zealous religiosity of believers in praxeological sphere, invokes to protect spiritually specific social groups by means of social service with care of marginalized society neglected because of different forms of otherness - reduced physical and mental capabilities, loneliness (homeless).

D. Chen and D. Lind suggest considering the religion as system of social insurance alternative to state insurance. In that case, if person is in social margin because of inborn or obtained otherness due to different terrific life conditions, the aid will be given by religious organization more effectively than by country (Chen, Lind, 2017). Researches K. Scheve and D. Stasavage insist that religion gives psychological defense mechanism in addition to the social support (Scheve, Stasavage, 2006: 255-286).

Quite a few of Ukrainian scientists researched caritative sphere of non-cult activity of the Christian churches. So, A. Slubska (2012: 215-227) researched interaction vectors between the Church, the country and civil society; V. Novikov (2008: 66-72) studied lawful aspects of charitable activity of religious organizations; N. Kulish analyzed interdenominational manifestations of social activity of religious communities in Ukraine (Kulish, 2016: 64-69). However, the majority of the researchers draw attention to the traditional directions of charitable work of the UGCC (pastoral counseling of prisoners, military people, spiritual and material support of different categories of destitute etc.), our paper is destined to the research of the specific spheres of the UGCC pastoral counseling by means of social service.

The goal of the paper is to define vectors of charitable activities of the UGCC in spheres concentrated on spiritual option of people from marginalized social environment (reduced physical and mental capabilities, homeless) in view of publication and new confessional media. Implementing this goal we solve the next tasks: to analyze different vectors of deaconion of the UGCC, to characterize features of social service as non-cult activities of denomination, to point out modern tendencies in charity service and delineate motives to the non-cult activity of priests and believers.

Presentation of the basic material. According to the informational materials of Razumkov Centre, almost third part $(31 \%)$ of interviewed could not decide if Churches participate actively in social and beneficial help, $21 \%$ claimed that "the Church does all possible and independent of it to help all destitute people". $23 \%$ drew attention that "their Church" did it like that and "others" could do more. $25 \%$ insisted that "the Church does not enough to help all who need it" (Religion and Church in Ukrainian society, 2017: 29). As Major Archbishop of the UGCC Svyatoslav accents, "the Church brings up its voice to defend the dignity of human and harmonic development of whole society on the ground of Law of God" (Religion and Church in Ukrainian society, 2017: 15).

In structure of the UGCC there is a department of social service (created on Episcopal Synod of the UGCC of 2016, where the main subject was deaconion, that was also when the strategy of community service was accepted). The department was created with the aim of organized, systematic and professional character, because over a period of independence Greek-Catholics by the forces of unindifferent initiatives of parishes, priests, believers, religious charity and civil organizations (for example, through the network of international charitable fund "Caritas Ukraine" that is official charity organization of the UGCC), church lay movements, monastic rites and congregations etc. developed different directions of social work: children and youth, families, lonely senior citizens, addicted to 
alcohol or drugs, health protection and healthy lifestyle promotion, social welfare of believers in community, migrants, people with functionality limitation, imprisoned, people without permanent place of residence, people which have suffered from natural disasters etc.

On Episcopal Synod of the UGCC that took place at 212 of September 2018 in Lviv-Briukhovychi the head of the social department Vasyl Tuchapets gave information about the development of social service of the UGCC. By efforts of the department, the book "With love serve each other", which contained stated theological aspects of social service, Holy Scripture, the teaching of the Church and practical suggestions about the organization and development of social service on parish, was published. There was also delivered chain of trainings and seminars for clerics and secular people. So, in the book it is particularly mentioned that "social service of the Church has faith in its ground and expresses deaconic nature of the Church... It is acclivity directed to solving of social problems and ensuring of social justice... Parochial level should be the ground of building functioning the neighbor serving" (Nagirnyak, ed., 2017: 5).

The social work is powerful missionary resource, because caritative activity is the most influential method of the Church kerygma delivering; such service for unchurched but potential neophytes is an attribute of "realness" of the Church. However, charitable activity has challenges for each community, as Fr. Yosafat Boyko accents: 1) "to devote oneself executively to the social service without effort at the "churched" life of that who we serve to; 2) to get accustomed to the fact that such only who is able to present projects for different foreign and mission organizations should be engaged in charitable activity" (Boyko, 2018: 10)

So, in our analysis of informational denominational environment we are going to distinguish node and the most significant points of the discourse that are concentrated on categories of Ukrainian society, which the UGCC draws the most attention on above all in its spiritual guardianship and care: indigent people with different forms of reduced capabilities and homeless people.

Spiritual guardianship of people with different forms of reduced physical and mental capabilities, serious diseases. The problem of the level of social and spiritual need gratification of different categories of people with disabilities, particularly children, is very urgent. So, according to the information of the Committee of healthcare of Verkhovna Rada of Ukraine, over a period of 2003-2012 the number of child population decreased by $19,02 \%$. At the same time, the number of children with disabilities is increasing by $0,5 \%$ every year. By the 1 of January 2014, it reached the index of 167059 people, or $2,0 \%$ of whole child population of Ukraine (Penitentiary pastoral service of the UGCC..., 2018).

The Church in its substance and historically attached the right and privilege of taking the first-priority care of physically and mentally indigent. In particular, the "Emmaus" Center was created under the UCU in 2001. The mission of this center is spreading of Christian vision of the gift and high calling of mentally disabled people, supporting them and their family, forming of community spirit and the gift of friendship with people with people with specific needs and indicating the dignity and the worth of each person. The activity of Center provides the spreading of new vision through enlightening presentations and seminars, preparation and distribution of editions and informational materials; the support of people with specific needs, their parents and volunteers by means of organization seminars of support, divisions, recollections, global prayers etc.; favoring private initiatives that correspond to the practical and spiritual inquiries of people with specific needs and their families, especially to their integration into the society (Center Emmaus, 2005: 24).

In March 2013 upon an initiative of rector Fr. Boris Gudzuk in Christian collegium named by patriarch Josyf Slipyj UCU the House "Emmaus" was opened. Mentally disabled people and their assistants-friends live there together. It is known that Jean Vanier and Marie-Hélène Mathieu (France) co-founded the "Faith and Light" association, in Ukraine similar association appeared at 1992 in Lviv. Nowadays there are more than 33 similar communities in our country; each of them unites about 30 people. The idea of Vanier was used as a basis of "Emmaus" House in UCU with the aim to open "special gift of friends with specific needs - gift of creating and studying authentic human relations" (Center, 2014: 1-3). The features of such community are: membership (people find their identity, implement their intention to the unity there), the right of being oneself, the confidence, the care, the participation, the center of healing and developing, the forgiveness, the mission (the prayer, help to the lonely, disappointed, dying; taking care of street children; fight for unity of Christians etc.), the openness (Characteristic features of the community, 2014: 4). The special area of work is pastoral counseling of parents of special children, maintenance by Christian psychologist through individual and pair meetings with parents of the child and with the whole family (Sanchishin, 2014: 40-41).

So, the only community in Zakarpattya, Khust community "Crag castle", which since 2012 has been headed by Mariana Albreht, educator of special children, also belongs to the communities of "Faith and Light". In this community families that raise children with disabilities can receive rehabilitation, medical and social assistance, education, communication, attention and learning games. Such form of the Christian service is "the test on the maturity for each parish, each Christian community. ... It is the sign of our realness" (Maksimenko, 2013: 19).

Deacon of the UGCC Oleg Plishilo patronizes the community of the deaf. During his education in Rome deacon with other two Ukrainian students (T. Geplinskiy and $M$. Mudryk) are putting into life the media-project with viral character for social networks "I pray in gestural language". This media-initiative consists of short videos that allow participating in prayer in gestural language. In the UGCC, there are three centers of pastoral counseling of people with hearing defects. Such community has been functioning since 2005 in the Archistratigus Michael's Church in Lviv, the particular Divine Liturgy is celebrated there in gestural language. Catechesis of such people is conducted in All Saints' Church in The Holy Virgin monastery. Similar pastoral counseling is performed in Ternopil and Drohobych. Pastoral counseling center for the deaf "Nadiya" functions in Lviv as well. It is engaged in publishing books for the deaf and unites them among themselves, it is conducted by Fr. O. Lazurkevich. And then Fr. M. Fenkanin and Fr. L. Mostovy hold a service in gesture language there in Lviv (Tkachenko, 2018).

Spiritual guardianship of homeless. In Ukraine there are from 16 thousands to 100 thousands of homeless people according to the different estimates. So, Catholic Lviv city civic organization "Community of mutual aid "Emaus-Oselya"' (established in 2001 with support of the "Emmaus" International Movement, that is made up of 
350 member organizations in almost 40 different countries) sustains financially the "Prosto Neba" journal that is the member of International Network of Street Papers. The mission of this civic organization is to help homeless people with finding the dignity in community, and then in society; to help the society with acceptance of each person and to spread ideas of the "Emmaus" Movement (The boundaries are obvious and imaginary, 2016).

The volunteers of the "Oselya" are Catholics, GrecoCatholics; also protestants, who know their calling and have a strong sense of responsibility for injustice of the world, homeless people and beggars, who could not become integrated into the society because of lost family and social relations, lost will to live after treatment for alcohol abuse, also join the affair. With the aim to disclose the number and needs of poor people, their attraction to creating community and self-organization, volunteers arranged the first public action of "Oselya" - organization of the Christmas Eve for beggars at 6th of January 2003 near St. George's Cathedral (Lviv). Organizers were overwhelmed by poverty incidence ( 80 place settings had been prepared, 250 people without certain place of residence, people with alcohol abuse, people with reduced capabilities, lonely people, retired people came) and this situation was found to be very inconspicuous in everyday life. Because of this, organizers decided to conduct similar Christmas Eves and Easter Breakfasts constantly.

In process of such social activity of "Oselya" it was figured out that the target group were people left on the margins of society by different reasons: addicted people who needed resocialization, people with reduced capabilities, homeless people, unemployed. The most effective form of the guardianship, which was actively used by Christians-volunteers in assistance with such people, were conversations that revealed the main problem of this social category - helplessness and incapability of overcoming the crisis without assistance. So, in "Oselya" there are favorable terms where lonely and homeless people can live, work together and take care of each other as in real family (Community of Emmaus-Oselya, 2018).

In parochial cafe "Vytania" (Lviv, Greek Catholic St. Vladimir and Olga Church, prior Fr. Bohdan Chaban) evangelical dinners for homeless are cooked. Confessor Fr. Bohdan Kalatin always begins them with prayer, than preaches and communicates personally with beggars (Yurakh, 2014: 40-43). Father-selesian Oleg Fedorenko is the director of Lviv city poorhouse, where he takes care of people torn by life, after illnesses, ex-prisoners etc. trying to bring them into society.

\section{Conclusions}

The UGCC sees realization of its triune mission in spiritual and charity option of believers and non-church people: to proclaim the Gospel (the kerygma), to sanctify (the liturgy) and to serve (the deaconion). Social activity is characterized by carrying out one own mission by means of non-cult service. Charitable non-cult activity is coordinated by social services department of the UGCC and is implemented by parochial priests, religious orders, and active believers-volunteers. The motivation to such actions is religious inducements and active citizenship.

Charitable activity of the UGCC with communities marginalized by society appears as socially significant activity aimed at spiritual recovery of the society by means of material and religious guardianship over unprotected and left on the margins of society, what promotes formation of active denominational volunteering movement.

\section{REFERENCES}

Chen, Daniel L. and Lind, Jo Thori (2017). The Political Economy of Beliefs: Why Fiscal and Social Conservatives/ Liberals Come Hand-in-hand. DOI: http://dx.doi.org/10.2139/ ssrn.2928766 (In English).

Scheve, Kenneth and Stasavage, David (2006). Religion and Preferences for Social Insurance. Quarterly Journal of Political Science: Vol. 1: No. 3: 255-286. DOI: http://dx.doi.org/10.1561/ 100.00005052 (In English).

Boyko, Y. (2018). Charity: Speak or not talk about her? Patriarchate. №4: 9-11. (In Ukranian).

Kordony yavni ta uyavni (2016). Prosto neba. №29. 38 s. (In Ukranian).

Kulish, N. (2016). Mizhkonfesiyni vyyavy sotsialnoyi diyalnosti relihiynykh splnot $v$ Ukrayini. Relihiya ta Sotsium (Chernivtsi), №1-2 (21-22): 64-69 (In Ukranian).

Nahirnyak, A. (ed.) (2017). Lyubovyu sluzhit odyn odnomu. Lohos, Lviv: 276 p. (In Ukranian).

Maksymenko, I. (2013). Symvol voskresinnya. Katolytskyy visnyk. №21: 19 (In Ukranian).

Novikov, V. V. (2008). Vektory vzayemodiyi Tserkvy, derzhavy ta hromadyanskoho suspilstva $v$ Ukrayini $v$ roky nezalezhnosti. Naukovi zapysky. Seriya "Istorychne relihiyeznavstvo". Ostroh: Vyd-vo NU "Ostrozka akademiya", Issue 1: 66-72 (In Ukranian).

Penitentsiarne dushpastyrstvo UHKTS bulo predstavleno na Mizhnarodniy konferentsiyi "Sotsialni aspekty kapelanstva: svit i Ukrayina". Retrieved from http://catholicnews.org.ua/penitenciarnedushpastirstvo-ugkc-bulo-predstavleno-na-mizhnarodniykonferenciyi-socialni-aspekti (In Ukranian).

Sociological research 'Relihiya i Tserkva v ukrayinskomu suspilstvi' (2017). Tserkva, suspilstvo, derzhava u protystoyanni vyklykam i zahrozam siohodennya (informatsiyni materialy). Tsentr Razumkova, 2017. 48 p. (In Ukranian).

Sanchyshyn, V. (2014). Suprovid osoblyvoyi simyi. Kana. №4: 40-41 (In Ukranian).

Slubska, A. Ya. (2012). Vektory vzayemodiyi Tserkvy, derzhavy ta hromadyanskoho suspilstva $v$ Ukrayini $v$ roky nezalezhnosti. Naukovi zapysky. Seriya "Istorychne relihiyeznavstvo". Ostroh: Vyd-vo NU 'Ostrozka akademiya', Issue 7: 215-227. (In Ukranian).

Spilnota vzayemodopomohy "Emaus-Oselya": misiya, tsinnosti, istoriya. Retrieved from http://emaus-oselya.org/ua/ ?page_id=4 (In Ukranian).

Tkachenko, R. (2018). Mova zhestiv - moya biolohichna mova. Retrieved from http://news.ugcc.ua/articles/mova_zhest\%D1\%96v__moya_mat $\%$ D $1 \% 96$ rna_b\%D1\%96olog\%D1\%96chna_mova_diyakon_oleg_pl\%D1\%96shilo_83528.html (In Ukranian).

Vanier, Jean (2014). Kharakterni rysy spilnoty: vybrani frahmenty z knyhy Zhana Vanye "Spilnota - mistse radosti $i$ proshchennya" (Trans. from French). Emaus: 4 (In Ukranian).

Zheplynskyy, T. (ed.) (2005). Blazhenni vbohi dukhom: Dar i poklykannya osib rozumovo nepovnospravnykh. Tsentr "Emaus" Svichado, Lviv, 24 s. (In Ukranian).

Yurakh, N. (2014). Dim "Emaus" v Kolehiumi UKU - poklyk do stosunkiv. Emaus: 1-3. (In Ukranian).

Yurakh, N. (2014). Kafe yak sluzhinnya. Kana. №8: 40-43. (In Ukranian).

\section{LIST OF REFERENCE LINKS}

Chen D. L., Lind J. T. The Political Economy of Beliefs: Why Fiscal and Social Conservatives/Liberals Come Hand-in-Hand. Philadelphia, 2017. DOI: http://dx.doi.org/10.2139/ssrn.2928766.

Scheve K., Stasavage D. Religion and Preferences for Social Insurance. Quarterly Journal of Political Science. 2006. № 3. p. 255-286.

Бойко Й. Благодійність: говорити чи не говорити про неї? Патріярхат. 2018. №4. С. 9-11. 
Кордони явні й уявні. Просто неба. 2016. № 29. 38 с.

Куліш Н. Міжконфесійні вияви соціальної діяльності релігійних спільнот в Україні. Релігія та Соціум. Чернівці, 2016. №1-2(21-22). С. 64-69.

Любов'ю служіть один одному. Посібник для організації соціального служіння у парафіях / ред. та упоряд. А. Нагірняк. Львів: Логос, 2017. 276 с.

Максименко І. Символ воскресіння. Католицький вісник. 2013. № 21. C. 19 .

Новіков В. В. Вектори взаємодії Церкви, держави та громадянського суспільства в Україні в роки незалежності. Наукові записки. Серія "Історичне релігієзнавство". Острог: Вид-во НУ "Острозька академія", 2008. Вип. 1. С. 66-72.

Пенітенціарне душпастирство УГКЦ було представлено на Міжнародній конференції "Соціальні аспекти капеланства: світ і Україна". Католицький оглядач. URL: http://catholicnews.org.ua/penitenciarne-dushpastirstvo-ugkc-bulo-predstavleno-namizhnarodniy-konferenciyi-socialni-aspekti (дата звернення 14.11.2018).

Релігія і Церква в українському суспільстві: соціологічне дослідження. Церква, суспільство, держава у протистоянні викликам і загрозам сьогодення (інформаційні матеріали). К.: Центр Разумкова, 2017. 48 с.
Санчишин В. Супровід особливої сім'ї. Кана. 2014. № 4. C. $40-41$.

Слубська А. Я. Вектори взаємодії Церкви, держави та громадянського суспільства в Україні в роки незалежності. Наукові записки. Серія "Історичне релігієзнавство". Острог: Вид-во НУ "Острозька академія", 2012. Вип. 7. С. 215-227.

Спільнота взаємодопомоги "Емаус-Оселя": місія, цінності, історія. URL: http://emaus-oselya.org/ua/?page_id=4 (дата звернення 10.12.2018).

Ткаченко P. Мова жестів - моя біологічна мова. URL: http:/ /news.ugcc.ua/articles/mova zhest\%D1\%96v moya mat\%D1\%96rna_b\%D1\%96olog\%D1\%96chna_mova_diyakon_oleg_pl\%D1\%96shilo 83528.html (дата звернення 10.01.2019).

Характерні риси спільноти: вибрані фрагменти з книги Жана Ваньє "Спільнота - місце радості і прощення". Емаус. 2014. С. 4.

Блаженні вбогі духом : Дар і покликання осіб розумово неповносправних / уклав Т. Жеплинський. Центр "Емаус". Львів: Свічадо, 2005. 24 с.

Юрах Н. Дім "Емаус" в Колегіумі УКУ - поклик до стосунків. Емаус. 2014. С. 1-3.

Юрах Н. Кафе як служіння. Кана. 2014. № 8. С. 40-43.

Филипчук Світлана,

Національний університет "Острозька академія" (м. Острог, Украйна)

e-mail: svitlana.fylypchuk@oa.edu.ua, ORCID 0000-0001-5345-328X

\section{СПЕЦИФІЧНІ СФЕРИ ХАРИТАТИВНОї ДІЯЛЬНОСТІ УГКЦ В СВІТЛІ КОНФЕСІЙНИХ МЕДІА: РЕЛІГІЕЗНАВЧИЙ АНАЛІЗ}

Стаття присвячена розгляду різних векторів дияконії Української греко-католицької церкви (УГКЦ) періоду незалежності України, виявленню ознак та основних тенденцій у соціальному служінні як позакультовій діяльності конфесії, окресленню мотиваційних спонук до такої позакультової роботи у священиків та вірян. Основним робочим інструментарієм для аналізу харитативної діяльності УГКЦ виступає емпіричний метод спостереження, за допомогою якого обґрунтовано, на які категорії соціуму найбільше спрямована благодійницька робота церкви, та метод узагальнення, завдяки якому автором виявлено сучасні тенденції в благодійному служінні та мотивації суб'єктів такого служіння. Уперше проаналізовано інформаційне конфесійне середовище із виокремленням вузлових й найбільш значимих точок дискурсу, що зосереджені на тих категоріях українського соціуму, яким УГКЦ приділяє найбільшу увагу в своїй духовній опіці та піклуванні: знедоленим з різними формами неповносправності й безхатченкам. Показано, що соціальна робота - це найвпливовіший спосіб донесення керигми Церкви, яке для потенційних неофітів виступає головною ознакою ії "справжності". Управлінська та координаційна функція Церкви в такій роботі має проявлятися в місії соціального служіння без "воцерковлення" об'єктів такого служіння та професійному підході, який полягає у вмінні чітко ставити задачі та виконувати їх в рамках благодійного проекту. Благодійна позакультова діяльність координується відділом соціального служіння УГКЦ, а реалізується парафіяльними священиками, чернечими орденами, активними вірянами-волонтерами. Мотивацією до таких дій є релігійні спонукання, а також активна громадянська позиція вірян. Благодійницька робота УГКЦ із маргіналізованими категоріями громадян постає як суспільно значуща діяльність із метою духовного оздоровлення суспільства через матеріальну й релігійну опіку незахищених і відкинених на маргінес верств населення, що сприяє фрормуванню активного конфесійного волонтерського руху.

Ключові слова: харитативна діяльність; ЗМІ; позакультова діяльність; УГКЦ.

\section{(C) Fylypchuk Svitlana}

Надійшла до редакції: 11.01.2019

Прийнята до друку: 20.02.2019 